\title{
STUDI TINGKAT LITERASI MEMBACA MAHASISWA SELAMA PEMBELAJARAN DARING
}

\author{
M. Nur Hakim \\ Universitas Cokroaminoto Palopo, Jalan Latammacelling No.19 Kota Palopo \\ nurhakim@uncp.ac.id
}

\begin{abstract}
ABSTRAK
Kegiatan pembelajaran daring dilakukan untuk menekan angka penyebaran covid-19. Melihat kondisi tersebut kegiatan belajar dapat dilakukan dengan memanfaatkan media teknologi sebagai sumber belajar. Kegiatan pembelajaran daring menuntut mahasiswa untuk tetap aktif dalam mengikuti proses belajar, seperti meningkatan literasi membaca. Namun, kenyataan yang terjadi di lapangan, masih banyak mahasiswa menghabiskan waktu hanya untuk bermain media sosial sebagi hiburan. Penelitian ini bertujuan untuk mendeskripsikan tingkat kemampuan literasi membaca mahasiswa selama diterapkan pembelajaran daring. Metode yang digunakan dalam penelitian ini ialah deskriptif kuantitatif. Teknik pengumpulan data dilakukan dengan menggunakan angket melalui formulir google dan melakukan wawancara untuk memperkuat data penelitian. Adapun analisis data dilakukan melalui teknik deskriptif kuantitatif. Data yang diperoleh dari hasil angket dipaparkan dengan bentuk persentase. Selanjutnya, data tersebut dideskripsikan untuk mengetahui tingkat kemampuan literasi membaca mahasiswa selama pembelajaran daring. Hasil penelitian menunjukkan bahwa tingkat literasi membaca mahasiswa selama diterapkan pembelajaran daring cukup efektif yang tampak dari rata-rata waktu yang digunakan mahasiswa dalam membaca sekitar $1-2$ jam dalam sehari dengan membaca referensi mata kuliah, menggunakan media sosial sebagai sumber belajar, dan membaca berita daring kerena memiliki kemudahan dalam mengakses informasi melalui gawai.
\end{abstract}

Kata Kunci : pembelajaran daring, literasi membaca, kemampuan membaca.

\begin{abstract}
Online learning activities are carried out to prevent the spread of covid-19. This is done by utilizing various media technological as a learning resource. Online learning activities require students to remain active in the learning process, such as increasing reading literacy. However, the reality is that many students still spend time just playing social media as entertainment. This study aims to describe the level of reading literacy skills of students during online learning. The method used in this research was descriptive quantitative. The data collection technique is done by using a questionnaire through google form and conducting interviews to strengthen the research data. The data analysis was carried out through quantitative descriptive techniques. The data obtained from the questionnaire results were presented in the form of a percentage. Furthermore, the data were described to determine the level of students' reading literacy skills during online learning. The results showed that the reading literacy level of students during online learning was quite effective as seen from the average time spent by students in reading around 1 - 2 hours a day by reading subject references, using social media as a learning resource, and reading online news. In short, it has been easy to access information through smartphone.
\end{abstract}

Keyword(s): online learning, reading literacy, reading skills.

DOI: https://doi.org/10.31943/bi.v6i1.112

\section{How to Cite:}

Hakim, M. N. (2021). STUDI TINGKAT LITERASI MEMBACA MAHASISWA SELAMA PEMBELAJARAN DARING . Bahtera Indonesia; Jurnal Penelitian Bahasa Dan Sastra Indonesia , 6(1), 77-87. https://doi.org/10.31943/bi.v6i1.112 


\section{PENDAHULUAN}

Membaca merupakan aktivitas yang dilakukan oleh seseorang untuk memeroleh informasi maupun untuk menambah wawasan. Aktivitas membaca dapat dilakukan oleh siapa saja, baik itu anak-anak, dewasa, maupun lansia. Hal ini disebabkan karena kegiatan membaca tidak ada batasan usia. Selama orang tersebut sudah mampu membaca, maka ia bisa melakukannya kapan saja dan di mana saja.

Perkembangan teknologi dan informasi hingga saat ini sangat memudahkan pembaca untuk mengakses informasi dengan cepat. Berbagai materi atau informasi dengan mudah didapatkan, baik berupa media cetak, seperti buku, majalah, koran maupun melalui media sosial atau berbagai berita yang dapat dibaca secara secara daring. Bahan bacaan juga dapat diakses dengan mudah oleh peserta didik melalui perpustakaan nasioanal dan internasional tanpa harus mengunjungi langsung perpustakaan tersebut dan cukup dari rumah semua literatur dapat dibaca. Kemudahan dalam mengakses literatur dengan cepat membuat pembaca untuk lebih giat lagi dalam membaca, apalagi peserta didik yang ingin mengerjakan tugas ataupun memperluas pengetahuan, tentunya dapat dilakukan dengan mengkses bahan bacaan melalui perpustakaan daring.

Saat ini seluruh kegiatan pembelajaran dilakukan secara daring, mulai dari tingkat dasar hingga perguruan tinggi. Sistem pembelajaran secara daring membuat pesrta didik untuk lebih banyak mengakses informasi atau materi pembelajaran melalui intrnet. Thamrin (2020) mengemukakan bahwa sistem pembelajaran daring memungkinkan peserta didik untuk memeroleh informasi melalui internet, serta dianggap sebagai sistem pembejaran yang menyenangkan dan fleksibel di masa pandemi covid-19 (Rakhmanina, dkk., 2020). Pendapat tersebut juga didukung oleh data awal yang ditemukan oleh peneliti bahwa sebagian besar mahasiswa Universitas Cokroaminoto Palopo banyak memanfaatkan kegiatan belajar daring dengan mengkses informasi atau sumber belajar melalui media internet bahkan beberapa juga mengungkapkan membaca melalui buku.

Membaca merupakan aktivitas berbahasa yang berkaitan dengan kemampuan reseptif. Hal ini karena kemampuan membaca dilakukan melalui proses menerima dan memahami informasi dari teks yang dibaca. Sebuah hasil penelitian diungkapkan oleh Mart (2015) bahwa untuk meningkatkan kemampuan peserta didik dalam membaca dapat dilakukan dengan menggabungkan teknik membaca ekstensif dan intensif. Hal ini didasarkan karena membaca membutuhkan kelancaran dan pemahaman dari teks yang dibaca. Pendapat yang sedikit berbeda juga dikemukakan Erfanpour (2013) bahwa kegiatan membaca ekstensif dapat memberikan dampak positif terhadap kemampuan peserta didik dalam memahami teks bacaan, serta dapat meningkatkan kemampuan tata bahasa dan kosakata (Habibollahi Aghdam \& Behroozizad, 2018). 
Kegiatan membaca dalam proses pembelajaran daring dapat menjadi salah satu hal penting untuk ditingkatkan oleh mahasiswa, mengingat sebagian besar aktivitas belajar mahasiswa digunakan untuk membaca. Namun, untuk memahami teks bacaan dapat dilakukan dengan meluangkan waktu untuk membaca. Perfetti, Landi, \& Oakhill (2005) mengemukakan bahwa salah satu cara untuk meningkatkan minat baca ialah dengan meluangkan banyak waktu untuk membaca dan memilih teks bacaan yang dianggap efektif atau merasa diminati. Pendapat tersebut didukung oleh pendapat Suragangga (2017) bahwa budaya literasi yang tertanam pada generasi muda khususnya kalangan pelajar dapat memengaruhi tingkat keberhasilan dalam lingkup pendidikan maupun kehidupan masyarakat.

Penelitian tentang literasi membaca sudah pernah dilakukan oleh Chairunnisa (2017) dengan metode penelitian survei menggunakan analisis jalur. Hasil penelitian mengungkapkan bahwa literasi membaca memiliki hubungan positif terhadap pemahaman bacaan. Hal tersebut tampak bahwa semakin tinggi literasi membaca seseorang, semakin tinggi juga pemahaman bacaan orang tersebut. Begitupun sebaliknya, semakin rendah literasi membaca seseorang, semakin rendah pula pemahaman bacaan seseorang. Metode penelitian survei tentang pembelajaran membaca juga pernah dilakukan oleh Rahayu, Winoto, dan Rohman (2016) dengan judul Kebiasaan membaca siswa Sekolah Dasar. Hasil penelitian mengungkapkan bahwa terdapat enam aspek yang diteliti dari kebiasaan membaca siswa. Pertama, aspek kesenangan membaca di perpustakaan/taman bacaan menyatakan merasa senang ketika menemukan buku yang ingin dibaca. Kedua, aspek intensitas menunjukkan bahwa aktivitas membaca dilakukan lebih dari 3 kali dalam seminggu dan mereka menggunakan waktu untuk membaca dalam sehari selama lebih dari lima belas (15) menit. Ketiga, jumlah buku yang dibaca siswa dalam waktu satu minggu kurang dari tiga buku dan 1 - 5 majalah. Keempat, sumber bacaan yang diperoleh siswa berasal dari perpustakaan. Kelima, aspek frekuensi mengunjungi perpustakaan/taman bacaan dalam seminggu sekitar dua (2) kali. Keenam, aspek frekuensi membaca buku dilakukan para siswa setiap hari serta mengenai jenis bahan bacaan yang disenangi para siswa pada umumnya buku cerita dan buku jenis fiksi lainnya.

Ibda (2019) melakukan penelitian dengan judul Pembelajaran Bahasa Indonesia Berwawasan Literasi Baru di Perguruan Tinggi dalam Menjawab Tantangan Era Revolusi Industri 4.0. Hasil penelitian Ibdah mengungkapkan bahwa pembelajaran bahasa Indonesia di perguruan tinggi berwawasan literasi baru sangat strategis dalam menjawab tantangan revolusi industri 4.0. Implementasi literasi dapat dilakukan melalui berbagai penguatan literasi, mulai dari penguatan literasi data, teknologi, dan literasi manusia dengan memanfaatkan Sistem Pembelajaran Daring 
Indonesia (SDPA). Selain itu, pemahaman mahasiswa dapat dibentuk melalui materi kebahasaan dengan meningkatkan keterampilan menulis dan berbicara berbasis data dan teknologi.

Hasil penelitian tentang literasi juga dilakukan oleh Siroj (2017) dengan mengembangkan model pusat kajian literasi untuk meningkatkan budaya mahasiswa dalam membaca. Hasil penelitian mengungkapkan bahwa pusat kajian literasi adalah wadah pengembangan gerakan literasi di perguruan tinggi yang dapat membantu meningkatkan budaya membaca di perguruan tinggi, baik melalui media konvensional atau media modern. Adapun untuk hasil uji coba dari ketiga model literasi yang sudah dikembangkan yaitu model fungsional, model praktik sosial budaya, dan pemberdayaan intelektual yang dipadukan dengan literasi digital dapat diketahui bahwa budaya membaca mahasiswa UNNES mengalami peningkatan.

Beberapa hasil penelitian terdahulu yang relavan dengan penelitian ini khususnya persamaan dari aspek pembelajaran daring maupun literasi membaca telah mengungkapkan beberapa temuan yang tentunya memberikan dampak terhadap literasi membaca. Beberapa hasil temuan dari peneliti sebelumnya menjadi dasar bagi peneliti dalam mengungkapkan letak perbedaan dari segi proses maupun temuan penelitian. Hasil penelitian sebelumnya belum ada yang mengungkapkan tentang tingkat literasi membaca mahasiswa selama dilakukan pembelajaran daring. Oleh karena itu, hasil penelitian ini terdapat perbedaan dari hasil penelitian sebelumnya, khususnya dari segi objek dan metode yang digunakan dalam penelitian ini.

Berdasarkan uraian yang telah dirumuskan terkait dengan permasalahan literasi membaca dan beberapa acuan dari penelitian relevan, maka dirumuskan masalah dalam penelitian ini, yaitu: Bagaimanakah tingkat kemampuan literasi membaca mahasiswa Universitas Cokroaminoto Palopo selama diterapkan pembelajaran?. Dari rumusan masalah tersebut, diuraikan tujuan dari penelitian ini ialah untuk mendeskripsikan tingkat kemampuan literasi membaca mahasiswa Universitas Cokroaminoto Palopo selama dilakukan pembelajaran daring.

\section{METODE PENELITIAN}

Penelitian ini merupakan jenis penelitian deskriptif kuantitatif yang bertujuan untuk mendeskripsikan tingkat kemampuan literasi membaca mahasiswa selama pembelajaran daring. Beberapa tahapan yang dilakukan dalam penelitian ini, yang dimulai dengan melakukan studi pendahuluan untuk mengetahui kegiatankegiatan yang dilakukan mahasiswa selama pembelajaran daring. Selanjutnya, mengumpulkan data penelitian menggunakan angket terhadap 60 responden melalui formulir google terkait dengan aspek-aspek literasi membaca selama pembelajaran daring, yang mencakup: 1) kegiatan yang dilakukan untuk 
menambah wawasan selama pembelajaran daring, 2) waktu yang digunakan untuk membaca selama pembelajaran daring, 3) jenis buku yang dibaca, 4) waktu yang tepat untuk membaca, dan 5) kegiatan membaca membuat wawasan tetap bertambah walapun pembelajaran dilakukan secara daring. Adapun pengumpulan data melalui wawancara untuk memperoleh informasi akurat sesuai dengan tujuan penelitian yang ingin dicapai.

Analisis data dalam penelitian ini melalui teknik deskriptif kuantitatif. Data yang diperoleh dari hasil angket dipaparkan dengan bentuk persentase. Selanjutnya, data tersebut dideskripsikan untuk mengetahui tingkat kemampuan literasi membaca mahasiswa selama pembelajaran daring.

\section{HASIL DAN PEMBAHASAN}

Hasil penelitian ini dijabarkan sesuai dengan angket tingkat kemampuan literasi membaca mahasiswa selama dilakukan pembelajaran daring. Temuan penelitian ini dibagi atas lima aspek dan dipaparkan hasil secara kuantitatif (berdasarkan tingkat persentase). Kelima aspek tersebut, yaitu: 1) kegiatan yang dilakukan untuk menambah wawasan selama pembelajaran daring, 2) waktu yang digunakan untuk membaca selama pembelajaran daring, 3) jenis bacaan, 4) waktu yang tepat untuk membaca, dan 5) kegiatan membaca membuat wawasan tetap bertambah walapun pembelajaran dilakukan secara daring.

1. Kegiatan yang Dilakukan untuk Menambah Wawasan Selama Pembelajaran Daring
Pernyataan pertama berkaiatan dengan kegiatan yang dilakukan mahasiswa untuk menambah wawasan selama pembelajaran daring. Tingkat persentase dari hasil angket seperti yang tampak pada gambar berikut.

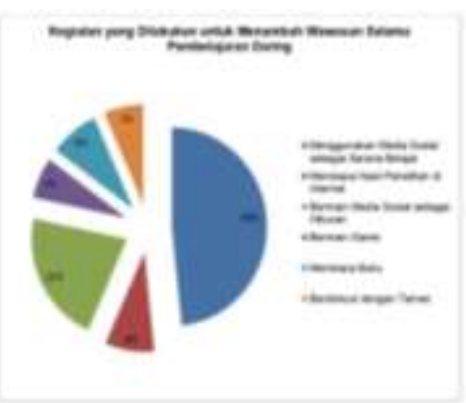

Gambar 1. Tingkat Persentase Kegiatan yang Dilakukan untuk Menambah Wawasan Selama Pembelajaran Daring

Sebanyak 60 responden diberikan angket untuk memberikan tanggapan terkait kegiatan yang dilakukan mahasiswa untuk menambah wawasan selama diterapkan pembelajaran daring. 60 responden telah memberikan tanggapan yang bervariasi, di antaranya: (1) sebanyak 29 responden (48\%) memberikan tanggapan menggunakan media sosial sebagai sarana belajar; (2) sebanyak 5 responden (8\%) memberikan tanggapan membaca hasil penelitian di internet; (3) sebanyak 13 responden (22\%) memberikan tanggapan bermain media sosial sebagai hiburan; (4) sebanyak 4 responden (7\%) memberikan tanggapan bermain game; (5) sebanyak 5 responden (8\%) memberikan tanggapan membaca buku; dan (6) sebanyak 4 responden (7\%) memberikan tanggapan berdiskusi dengan teman.

Berdasarkan temuan penelitian yang telah dipaparkan tampak bahwa aktivitas yang Fakultas Keguruan dan Ilmu Pendidikan 
dilakukan mahasiswa selama kegiatan pembelajaran daring cukup bervariasi. Sebagian besar mahaiswa melakukan aktivitas dengan menggunakan media sosial sebagai sarana untuk kegiatan belajar. Temuan ini diperkuat dari hasil wawancara yang dilakukan peneliti bahwa mahasiswa cenderung menggunakan media Youtube sebagai salah satu cara untuk mecari materi pembelajaran. Selain itu, tidak sedikit juga responden yang memberikan tanggapan menggunakan media sosial hanya sebagai hiburan, seperti bermain game, facebook, instagram, dan berbagai media sosial lainnya. Adapun yang terlibat dalam kegiatan membaca buku dan berdikusi hanya beberapa responden. Dari temuan ini, tampak bahwa aktivitas mahasiswa selama pembelajaran daring telah memberikan dampak yang cukup positif karena sebagian besar kegiatan dilakukan untuk proses belajar dan membaca untuk memeroleh pengetahuan dan wawasan. Temuan ini sejalan dengan hasil penelitian yang diungkapkan Fitriyani, Fauzi, \& Sari (2020) bahwa motivasi mahasiswa dalam kegiatan belajar selama dilakukan pembelajaran daring menunjukkan hasil yang sangat baik, yang tampak pada sikap konsentrasi, rasa ingin tahu, semangat, kemandirian, kesiapan, antusias, dan pantang menyerah.

2. Waktu yang Digunakan untuk Membaca selama Pembelajaran Daring

Pernyataan kedua berkaitan dengan lama waktu yang digunakan mahasiswa untuk membaca selama pembelajaran daring. Tingkat persentase dari hasil angket seperti yang tampak pada gambar berikut.

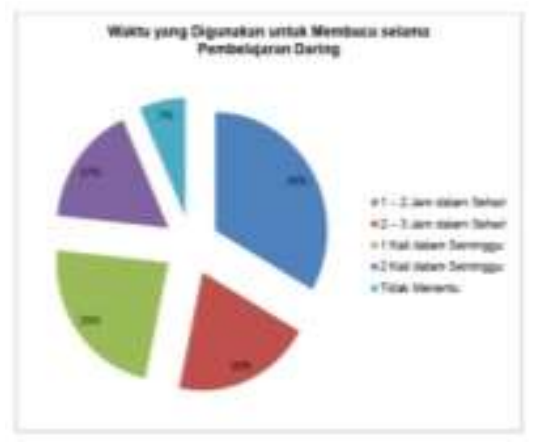

Gambar 2. Tingkat Persentase Waktu yang Digunakan untuk Membaca selama Pembelajaran Daring

Sebanyak 60 responden diberikan angket untuk memberikan tanggapan terkait dengan lama waktu yang digunakan dalam membaca selama pembelajaran daring. Tampak dari 60 responden telah memberikan tanggapan yang bervariasi, di antaranya: (1) sebanyak 20 responden (33\%) memberikan tanggapan $1-2$ jam dalam sehari; (2) 12 responden (20\%) memberikan tanggapan $2-3$ jam dalam sehari; (3) 14 responden (23\%) memberikan tanggapan 1 kali dalam seminggu; (4) 10 responden (17\%) memberikan tanggapan 2 kali dalam seminggu; dan (5) sebanyak 4 responden (7\%) memberikan tanggapan tidak menentu.

Data temuan ini memberikan gambaran bahwa selama pelaksanaan pembelajaran daring tampak bahwa tingkat literasi membaca mahasiswa sedikit meningkat karena sebagian besar responden memberikan tanggapan waktu yang digunakan membaca sekitar $1-2$ jam dalam sehari. Namun, dari beberapa responden juga masih terlihat kurang dalam membaca. Hal inilah yang menjadi tugas bersama, baik itu 
pendidik ataupun peserta didik untuk dapat meningkatkan literasi membaca mereka dengan menerapkan berbagai strategi untuk memberikan stimulus kepada peseta didik agar memiliki minat dalam membaca. Sebagaimana dikemukakan Sofyan (2016) bahwa minta membaca merupakan sikap senang yang ditunjukkan seseorang terhadap bacaan karena adanya pemikiran bahwa dengan membaca dapat memberikan manfaat bagi pembaca.

3. Jenis Bacaan

Pernyataan ketiga berkaiatan dengan jenis bacaan yang digunakan mahasiswa selama pembelajaran daring. Tingkat persentase dari hasil angket seperti yang tampak pada gambar berikut.

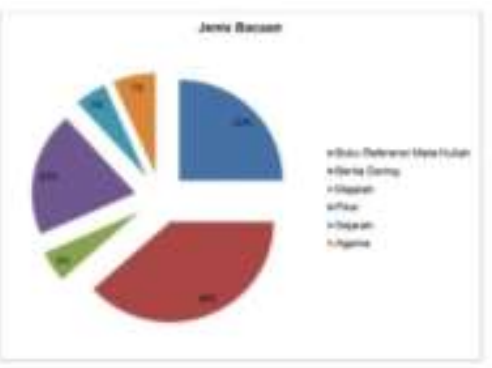

Gambar 3. Tingkat Persentase Jenis Bacaan yang Dipilih Mahasiswa selama Pembelajaran Daring

Sebanyak 60 responden diberikan angket untuk memberikan tanggapan terkait dengan jenis bacaan yang digunakan mahasiswa selama pembelajaran daring. Tampak dari 60 responden telah memberikan tanggapan yang bervariasi, di antaranya: (1) sebanyak 15 responden (25\%) memberikan tanggapan jenis bacaan berupa referensi mata kuliah, baik yang diberikan langsung oleh dosen maupun yang diperoleh melalui internet; (2) sebanyak 23 responden
(38\%) memberikan tanggapan jenis bacaan berupa berita daring; (3) sebanyak 3 responden (5\%) memberikan tanggapan jenis bacaan berupa majalah; (4) sebanyak 12 responden (20\%) memberikan tanggapan jenis bacaan berupa fiksi; (5) sebanyak 3 responden (5\%) memberikan tanggapan jenis bacaan berupa sejarah; dan (6) sebanyak 4 responden (7\%) memberikan tanggapan berupa buku agama.

Jenis bacaan merupakan salah satu aspek yang dapat menentukan kecintaan peserta didik untuk rajin membaca. Dari data temuan pada penelitian ini tampak bahwa rata-rata responden memberikan tanggapan bahwa jenis bacaan yang sering dibaca berupa referensi mata kuliah dan berupa berita daring yang diakses melalui gawai. Hasil wawancara mengungkapkan bahwa tingginya pemilihan minat baca pada referensi mata kuliah dikarenakan mahasiwa ingin mengetahui lebih dalam dari mata kuliah yang dipelajari sesuai dengan disiplin ilmu mereka dan tentunya membaca referensi mata kuliah juga karena ingin mengerjakan tugas yang diberikan oleh dosen pengampu mata kuliah. Selain itu, mahasiswa juga banyak meluangkan waktu untuk membaca berita daring. Dari hasil wawancara mengungkapkan bahwa mahasiswa sangat tertarik membaca berita daring karena kemudahan dalam mengakeses berita melalui gawai dan untuk lebih mengetahui informasi terbaru. Temuan ini sejalan dengan hasil penelitian yang diungkapkan Hardianto (2011) bahwa jenis bacaan yang diminati mahasiswa berupa buku-buku yang bersifat populer karena 
informasi yang disampaikan penulis memiliki unsur kebaruan, pemaparan isi yang bervariatif, dan isi teks yang tidak monoton.

4. Waktu yang Tepat untuk Membaca

Pernyataan keempat berkaiatan dengan waktu yang tepat bagi mahasiswa untuk membaca selama kegiatan pembelajaran daring. Tingkat persentase dari hasil angket seperti yang tampak pada gambar berikut.

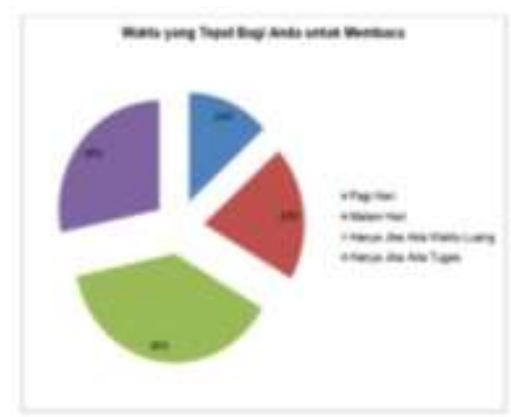

Gambar 4. Tingkat Persentase Waktu yang Tepat untuk Membaca

Sebanyak 60 responden diberikan angket untuk memberikan tanggapan berkaiatan dengan waktu yang tepat bagi mahasiswa untuk membaca selama kegiatan pembelajaran daring. Tampak dari 60 responden telah memberikan tanggapan yang bervariasi, di antaranya: (1) sebanyak 8 responden (13\%) memberikan tanggapan membaca dilakukan di pagi hari; (2) sebanyak 12 responden (20\%) memberikan tanggapan membaca dilakukan di malam hari; (3) sebanyak 23 responden (39\%) memberikan tanggapan membaca dilakukan hanya jika ada waktu luang; dan (4) sebanyak 17 responden (28\%) memberikan tanggapan membaca dilakukan hanya jika ada tugas.
Memahami sebuah bacaan diperlukan cara atau teknik dalam membaca maupun disesuaikan dengan suasana yang diinginkan oleh pembaca agar bisa terfokus untuk membaca. Hasil temuan dalam penelitian ini tampak bahwa rata-rata responden memilih malam hari dan membaca dilakukan jika hanya ada waktu luang. Dari data tersebut menandakan bahwa kebanyakan mahasiswa belum mampu mengatur waktu dengan baik untuk kegiatan membaca. Padahal untuk meningkatkan tingkat literasi membaca, dibutuhkan manajeman waktu yang baik agar porsi membaca dapat dilakukan secara terstruktur. Hal ini sesuai dengan pendapat yang dikemukakan Perfetti, Landi, \& Oakhill (2005) bahwa salah satu cara untuk meningkatkan minat baca ialah dengan meluangkan banyak waktu untuk membaca dan memilih teks bacaan yang dianggap efektif atau merasa diminati.

5. Membaca Membuat Wawasan Tetap Bertambah Walapun Pembelajaran

Dilakukan Secara Daring

Pernyataan kelima berkaiatan dengan kegiatan membaca dapat menambah wawasan, walaupun pembelajaran dilakukan secara daring. Tingkat persentase dari hasil angket seperti yang tampak pada gambar berikut. 


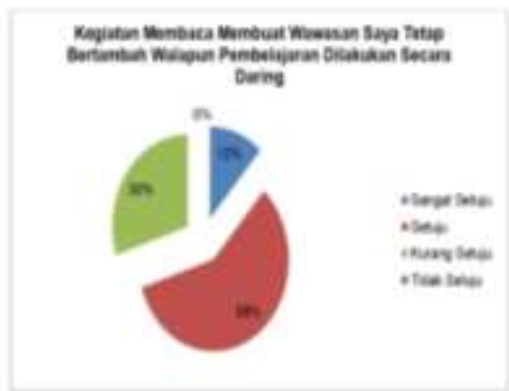

Gambar 5. Tingkat Persentase Membaca Membuat Wawasan Tetap Bertambah Walapun Pembelajaran Dilakukan Secara Daring

Sebanyak 60 responden diberikan angket untuk memberikan tanggapan berkaiatan dengan kegiatan membaca dapat menambah wawasan, walaupun pembelajaran dilakukan secara daring. Tampak dari 60 responden telah memberikan tanggapan yang bervariasi, di antaranya: (1) sebanyak 7 responden (12\%) memberikan tanggapan sangat setuju; (2) sebanyak 35 responden (58\%) memberikan tanggapan setuju; (3) sebanyak 18 responden (30\%) memberikan tanggapan kurang setuju; dan (4) tidak ada responden (0\%) yang memberikan tanggapan tidak setuju.

Proses pembelajaran daring yang masih terus berlanjut sampai saat ini menuntut kesadaran mahasiswa untuk dapat belajar secara mandiri. Kegiatan belajar mandiri dilakukan dengan memanfaatkan aktivitas membaca secara efektif untuk menambah wawasan.
Patiung (2016) mengungkapkan bahwa kegiatan membaca memberikan manfaat untuk memahami seluruh informasi yang tertera dalam teks bacaan sebagai bekal ilmu pengetahun, menambah kosakata, serta memperluas pemikiran pembaca itu sendiri. Adapun data dari temuan penelitian ini mengungkapkan bahwa sebagian besar responden menyatakan setuju bahwa dengan pelaksanaan pembelajaran daring wawasan tetap bertambah karena aktivitas diisi dengan kegiatan membaca walupun tidak ada kontrol langsung dari dosen. Namun, sebagian responden juga menyatakan kurang setuju dari kegiatan pembelajaran daring karena materi tidak disampaikan langsung secara tatap muka yang membuat peserta didik terkadang sulit untuk memilah materi bacaan yang sesuai.

\section{SIMPULAN}

Adanya bencana covid-19 yang melanda seluruh penjuru dunia termasuk Indonesia mendorong kegiatan proses belajar mengajar dilakukan secara daring. Kegiatan belajar daring harus tetap menekankan kepada mahasiswa untuk selalu aktif dalam mengikuti kegiatan belajar, seperti meningkatan aktivitas dalam membaca karena untuk memperlus pengetahuan salah satunya dilakukan dengan membaca. Hasil penelitian ini mengungkapkan bahwa tingkat literasi membaca mahasiswa selama dilakukan pembelajaran dapat dikatakan cukup efektif. Hal tersebut tampak dari data temuan di antaranya: 1) sebagian besar responden menggunakan media sosial sebagai sumber belajar; 2) rata-rata waktu yang digunakan mahasiswa dalam

Fakultas Keguruan dan Ilmu Pendidikan 
membaca sekitar 1 - 2 jam dalam sehari; 3) jenis bacaan yang paling banyak diminati oleh mahasiswa berupa buku referensi mata kuliah dan berita daring karena kemudahan dalam mengakses berita melalui gawai; 4) waktu yang digunakan mahasiswa dalam membaca ialah di malam hari dan hanya jika ada waktu luang; dan 5) sebagian besar responden menyatakan setuju bahwa dengan pelaksanaan pembelajaran daring wawasan tetap bertambah karena aktivitas diisi dengan kegiatan membaca. Olehnya itu, melalui penelitian ini, penulis merekomendasikan kepada peneliti lanjut untuk mengembangkan penelitian ini, khususnya pada responden yang lebih besar dan menyarankan pada semua pihak untuk aktif dalam meningkatkan literasi membaca.

\section{DAFTAR PUSTAKA}

Chairunnisa, C. (2018). Pengaruh Literasi Membaca dengan Pemahaman Bacaan (Penelitian Survei pada Mahasiswa STKIP Kusumanegara Jakarta). Jurnal Tuturan, 6(1), 745-756.

Erfanpour, M. A. (2013). The Effect of Intensive and Extensive Reading Strategies on Reading Comprehension: A Case of Iranian High School Students. English for Specific Purposes World, 14(41), 121.

Fitriyani, Y., Fauzi, I., \& Sari, M. Z. (2020). Motivasi Belajar Mahasiswa pada Pembelajaran Daring Selama Pandemi Covid-19. Jurnal Kependidikan: Jurnal Hasil Penelitian dan Kajian Kepustakaan di Bidang Pendidikan, Pengajaran dan Pembelajaran, 6(2), 165-175.
Habibollahi Aghdam, M., \& Behroozizad, S. (2018). Directed Reading-Thinking Activity and Reading Comprehension. Journal of English Language Pedagogy and Practice, 11(22), 111-126.

Hardianto, D. (2011). Studi Tentang Minat Baca Mahasiswa Fakultas Ilmu Pendidikan UNY. Majalah Ilmiah Pembelajaran, 7(1).

Ibda, H. (2020). Pembelajaran Bahasa Indonesia Berwawasan Literasi Baru di Perguruan Tinggi dalam Menjawab Tantangan Era Revolusi Industri 4.0. Jalabahasa, 15(1), 48-64.

Mart, C. T. (2015). Combining Extensive and Intensive Reading to Reinforce Language Learning. Journal of Educational and Instructional Studies in the World, 5(4), 85-90.

Patiung, D. (2016). Membaca Sebagai Sumber Pengembangan Intelektual. Al Daulah: Jurnal Hukum Pidana dan Ketatanegaraan, 5(2), 352-376.

Perfetti, C. A., Landi, N., \& Oakhill, J. (2005). The Acquisition of Reading Comprehension Skill. The Science of Reading: A Handbook, 227-247. doi:10.1002/9780470757642.ch13.

Rahayu, W., Winoto, Y., \& Rahman, A. S. (2016). Kebiasaan Membaca Siswa Sekolah Dasar (Survei Aspek Kebiasan Membaca Siswa SD Negeri 2 Pinggirsari di Desa Pinggirsari Kecamatan Arjasari Kabupaten Bandung). Khizanah alHikmah: Jurnal Ilmu Perpustakaan, Informasi, dan Kearsipan, 4(2), 152162.

Rakhmanina, L., Martina, F., Halolo, F. B., Syafryadin, S., \& Noermanzah, N. (2020). Students' Perception on Online English Learning during Covid-19 Pandemic Era. Silampari Bisa: Jurnal Penelitian Pendidikan Bahasa Indonesia, Daerah, Dan Asing, 3(2), 428-439.

Siroj, M. B. (2017). Pengembangan Model Pusat Kajian Literasi guna Meningkatan Budaya Membaca Mahasiswa Universitas Negeri Semarang. 
Suragangga, I. M. N. (2017). Mendidik Lewat Literasi untuk Pendidikan Berkualitas. Jurnal Penjaminan Mutu, 3(2), 154-163.

Sofyan, M. H. A. (2016). Meningkatkan Motivasi Membaca. IQRA: Jurnal Ilmu Perpustakaan dan Informasi (eJournal), 9(2), 1-11.

Thamrin, L. (2020). Pembelajaran Daring Dosen Native Tiongkok terhadap Mahasiswa FKIP Universitas Tanjungpura. Silampari Bisa: Jurnal Penelitian Pendidikan Bahasa Indonesia, Daerah, Dan Asing, 3(2), 406-427. 